\title{
E- BUSINESS
}

\section{Mr. Govind Chaudhary-M.Phil ${ }^{1}$, Sanjay Kumar Patel ${ }^{2}$, Kaish Momad Anshari (M.Phil) ${ }^{3}$}

\author{
${ }^{1}$ Research scholar, Awadhesh Pratap Singh University, Rewa Madhya Pradesh \\ ${ }^{2}$ Assistant professor, Awadhesh Pratap Singh University, Rewa Madhya Pradesh \\ ${ }^{3}$ Awadhesh Pratap Singh University, Rewa, Madhya Pradesh
}

\begin{abstract}
Online Business or e-business is any kind of business or commercial transaction that includes sharing information across the internet. commerce constitutes the exchange of products and services between businesses, groups, and individuals and can be seen as one of the essential activities of any business. Electronic commerce focuses on the use of information and communication technology to enable the external activities and relationships of the business with individuals, groups, and other businesses, while e-business refers to business with help of the internet. Electronic business differs from electronic commerce as it does not only deal with online transactions of selling and buying of a product and/or service but also enables to conduct of business processes (inbound/outbound logistics, manufacturing \& operations, marketing and sales, customer service) within the value chain through internal or external networks.The term "e-business" was coined by IBM marketing and Internet team 1999
\end{abstract}

Keywords : e-business or online exchange products

\section{INTRODUCTION}

E-business or Online business means business transactions that take place online with the help of the internet. The term ebusiness came into existence in the year 1996. E-business is for electronic business. So the buyer and the seller don't meet personallIn today's world, we are exposed to various forms of e-Business. Since its emergence.

Michele aldrech is considered the developer of the predecessor to online shopping. In 1979, the entrepreneur connected a television set to a transaction processing computer with a telephone line and called it "teleshopping", meaning shopping at distance. From the mid-nineties, major advancements were made in the commercial use of the Internet. amazon which launched in 1995, started as an online bookstore and grew to become nowadays the largest online retailer worldwide, selling food, toys,

After conducting worldwide market research in October 1997, IBM began with an eight-page piece in that would introduce the concept of "e-business" and advertise IBM's expertise in the new field. IBM decided not to trademark the term "e-business" in the hopes that other companies would use the term and create an entirely new industry. ${ }^{[}$However, this proved to be too successful and by 2000, to differentiate itself, IBM launched a $\$ 300$ million campaign about its "ebusiness infrastructure" capabilities. [ Since that time, the terms, "e-business" and "e-commerce" have been loosely interchangeable and have become a part of the common vernacular.According to the U.S. Department Of Commerce, the estimated retail e-commerce sales in Q1 2020 were representing almost $12 \%$ of total U.S. retail sales, against $4 \%$ for Q1 2011.

\section{METHODOLOGY}

An in-depth literature review of 30 journals published between the years 2000 and 2019 has been undertaken from which 100 studies have been selected. The selection criteria of these studies have primarily been keyword searches such as -e-commerce, e-business, and internetll. Furthermore the agendas of most recent conferences surrounding the -ell - theme have been analyzed

\section{BUSINESS MODEL}

most part includes making and conveying an online business site. The initial phase in the advancement of a web based business website is to distinguish the web based business model. Depending on the gatherings associated with the exchange, web based business can be characterized into principle 4 models. These are discussing as pursues:

\section{Business-to-Business (B2B)}

Demonstrate This is said to be the quickest developing area of online business. The B2B display is anticipated to end up the biggest esteem segment of the business inside a couple of years. The B2B demonstrate includes electronic exchanges for requesting, obtaining, and in addition other administrative assignments between houses. 


\section{Business-to-Customer (B2C)}

Show The B2C display includes exchanges between business associations and buyers. It applies to any business association that pitches its items or administrations to shoppers over the Internet. These locales display product data in an online list and store it in a database. The $\mathrm{B} 2 \mathrm{C}$ model additionally incorporates administrations internet managing an account, travel administrations, and wellbeing information.

\section{Consumer-to-Customer (C2C)}

Demonstrate The $\mathrm{C} 2 \mathrm{C}$ show includes exchange between purchasers. Here, a shopper offers straightforwardly to another purchaser. Online sale Web sites that give a shopper to promote and offer their items online to another consumer.

\section{Consumer-to-Business (C2B)}

Display The C2B display includes an exchange that is directed between a buyer and a business organization. It is like the $\mathrm{B} 2 \mathrm{C}$ demonstrate, in any case, the thing that matters is that for this situation the consumer is the dealer and the business association is the purchaser. In this sort of an exchange, the consumers choose the cost of a specific item instead of the provider. This classification includes individuals who pitch items and administrations to associations. Notwithstanding the models talked about up until now, five new models are being dealt with that involves transactions between the legislature and different substances, for example, purchaser, business organizations, and different governments.

\section{Government-to-Government (G2G)}

Demonstrate: This model includes exchanges between 2governments. For instance, if the Pakistani government needs to by oil from the Arabian government, the exchange included are arranged in the G2G demonstrate. b) Governmentto-Buyer (G2C) Show: In this model, the administration executes within singular customer. For instance, an administration can authorize laws relating to tax payments on individual shoppers over the Web by utilizing the G2C demonstrate. c) Consumer-to-Government (C2G) Demonstrate: In this model, an individual shopper interacts with the 2.Features of Online Business

Some of the features of Online Business are as follows :

- $\quad$ It is easy to set up

- $\quad$ There are no geographical boundaries

- $\quad$ Much cheaper than traditional business

- $\quad$ There are flexible business hours

- $\quad$ Marketing strategies cost less

- $\quad$ Online business receive subsidies from the government

- $\quad$ There are a few security and integrity issues

- There is no personal touch

- $\quad$ Buyer and seller don't meet

- Delivery of producte takes time

- $\quad$ There is a transaction risk

- $\quad$ Anyone can buy anything from anywhere at anytime

- The transaction risk is higher than traditional business

\section{RESULTS}

It is evident that the lack of research in governance and ethics issues in past research, that Drew (2007) discovered ten years ago, still holds true today. This study also substantiates the argument by Athanassakos (2010), who asserts that there are very few studies on corporate valuation of e-businesses. Also, the finance literature does not contain much notable research on the stock market's response to e-business mergers and the technology crash, except for a couple of studies (Park \& Mezias, 2005). Another interesting but neglected area, is that of intellectual capital in the e-business context., The subsequent year an empirical study has been conducted on digital capital indicators in the Taiwanese Banking sector (Chang, 2007). Another Taiwanese study related to the value creation potential of intellectual capital in the digital capital industry has been published only recently (Hsiung \& Wang, 2012). To the author's best knowledge, the only study related directly to e-business models and intellectual (or digital) capital is a conference proceeding published by (Gholamian et al., 2010). Table 3 provides a condensed overview of emerging trends $-\mathrm{T} \|$ and still popular themes - ST\|. 


\section{THE ADVANTAGES OF WEB BASED BUSINESS TO BUSINESS, SHOPPERS AND SOCIETY}

The past segments have included discourses about what internet business is and its effect, however what are the advantages of online business? What does it offer and for what reason do it? The advantages of web based business can be believed to influence three major partners: Business Associations, Buyers and Society. 1. Benefits of Web based Business to Business a) International Commercial center - What used to be a solitary physical marketplace located in a land zone has now turned into a borderless marketplace including national and universal markets? By getting to be ecommerce enabled, organizations presently approach individuals all around the globe. In effect all web based business organizations have turned out to be virtual multinational corporations. b) Operational Cost Reserve Funds - The expense of making, handling, distributing,

. It is likewise less expensive to send a fax or email by means of the Web than direct dialing. e) Digitization of Items and Procedures - Especially on account of software and music/video items, this can be downloaded or messaged specifically to clients by means of the Web in computerized or electronic organization. f) No More 24-Hour-Time Imperatives - Organizations can be reached by or contact clients or providers whenever. 2. Benefits of Internet business to Shoppers a) 24/7 Access - Empowers clients to shop all year from any area. For acquiring travel and other data. or on the other hand lead different exchanges 24hours per day, all model - checking balances, making installment

\section{CONCLUSION}

The digital revolution with all its novelties and challenges, will force researchers to re-evaluate their respective past studies. For instance, the very popular sub-topic of e-business strategy; -e-business models\| will now need to be updated to encompass seamless integration of multi-channels. Papers on — critical success factors $\|$ and — key drivers in e-commerce\| call for re-investigation in light of the social network explosion creators, advertising specialists, social media experts and digital marketers, the demand for social site engineers is rising. Website quality literature, still a very hot topic, will be expanded to encompass topics such as continuous optimization techniques, content management, responsive design and seamless integration of etc. al., 2010), remain popular. WEB 3.0-intensive literature will soon be replaced with research in the Web.

\section{REFERENCES}

1. e-business - genesis of electronic business [in Polish], http://www.heuristic.pl/blog/e-biznes/159.html, access date 10.12.2014.

2. Benicewicz-Miazda A., E-business on the Internet and in multimedia [in Polish]. MIKOM, 2003, p. 6-8.

3. Żurak-Owczarek C., E-business on global and local scales. Analysis and an evaluation attempt [in Polish], Łódź 2013 , p. 16.

4. Tomasz Teluk T. E-business. New economy [in Polish], ONE PRESS, Gliwice 2002, pp. 104-107.

5. Enterprise environment [in Polish], http://www.findict.pl/slowTiik/otoczenie-przedsiebiorstwa. access date 12.12.2014

6. Pawełoszek-Korek I., Electronic commerce and business [in Polish], http://w- ww.paweloszek.republika.pl/ecommerce.html. access date 12.12.2014.

7. Amir Hartman A., Sifonis J. Kador J. E-business, success strategies in the internet economy. Tried and tested methods for organising ebusinesses [in Polish]. Liber, Warszawa 2001, pp. 116-156.

8. Śliwiński M. Business models of e-services [in Polish], Warszawa 2008, pp. 5-6. 9. Nojszewski D. Overview of e-business models (part I) [in Polish], E-mentor, dwumiesięcznik Szkoły Głównej Handlowej w Warszawie, no 5 (17)/ 2006.

10. Jelonek D. Competitive advantage of e-enterprise [in Polish]. Ekonomika i Organizacja Przedsiębiorstwa 3 (2003): 26-38.

11. Okonek P. Marketing strategies and plans for e-services [in Polish]. Warszawa 2010, pp. 6-7.

12. Frąckiewicz E. Internet marketing [in Polish]. PWN, Warszawa 2006, p. 34-40.

13. Internet services, http://www.ideo.pl/emarketing/serwisv internetowe/, access date 15.12.2014.

14. Dejnaka A., Blogs as an e-marketing tool [in Polish], in: Biblia e-biznesu, Gliwice 2013, p. 192.

15. 6 most popular e-marketing tools [in Polish], http://www.heuristic.pl/blog/e-marketing/96.html. access date 13.12.2014.

16. Social marketing [in Polish], http://socialpress.pl/stronv/marketing-spolecznosciowv/. access date 12.12.2014.

17. Advantages of e-mail marketing [in Polish], http://www.expertsender.pl/email-marketing/zalety-email-marketingu, access date 12.12.2014.

18. Multiple autoresponder [in Polish], http://ebiznesv.pl/e-marketing/e-mail-marketing/wielokrotnv-autoresDonder. accessdate 27.12.2014.

19. What are sąueeze pages [in Polish], http://iaceksztucki.pl/571/co-to-iest-saueeze-pages/. access date 28.12.2014.

20. Virtual enterprise in the economic practice [in Polish], http://www.logistvkafirm.com/transport art.php?did=1\&aid=165\&p=\&cat $=1 \&$ catname $=$. access date 28.12.2014 